\title{
Pengaruh Kualitas Sarana dan Prasarana terhadap Minat Belajar Siswa dalam Pembelajaran Pendidikan Agama Islam
}

\author{
Sinta Kartika \\ Institut Agama Islam Darussalam (IAID) Ciamis, Jawa Barat. \\ Email: sinta_kartikaiaid@gmail.com \\ Husni \\ Program Pascasarjana, Institut Agama Islam Darussalam (IAID) Ciamis, Jawa Barat. \\ Email: husni1967@yahoo.co.id \\ Saepul Millah \\ Institut Agama Islam Darussalam (IAID) Ciamis, Jawa Barat. \\ Email: saepulmillah.iaid@gmail.com \\ Received: Desember 1, 2018 | Accepted: March 3, 2019
}

\begin{abstract}
This research article found that: (1) The quality of facilities and infrastructure at SMK AL Huda Turalak has an average rate of 46.83 classified as medium clarification because it is in the range of scores between 46.15 to 52.00; (2) The learning interest of SMK AL Huda Turalak students has an average of 47.32, it is included in the medium category because it is in the range of scores between 46.15 to 52.00; (3) There is an influence between the quality of facilities and infrastructure on students' interest in learning at Al-Huda Turalak Vocational School. This is obtained from the analysis of SPSS 20, from the analysis it is known that the sig (2-tailed) value of $0.001<0.05$, then $\mathrm{H} 0$ is rejected and the correlation coefficient value of 0.405 is classified as moderate interpretation. From the data above shows that there is an influence between the quality of facilities and infrastructure on students' interest in learning PAI at Al-Huda Turalak Vocational School. Then the correlation is $r=0.405$ or $40.5 \%$, and the number lies in the number $0.410-0.60$, meaning the correlation between the $\mathrm{X}$ variable and the $\mathrm{Y}$ variable is moderate. While $59.5 \%$ of student interest is influenced by other factors.
\end{abstract}

\begin{abstract}
Abstrak
Artikel penelitian ini menemukan bahwa: (1) kualitas sarana dan prasarana di SMK AL Huda Turalak mempunyai nlai rata-rata sebesar 46,83 tergolong pada klarifikasi sedang karena berada pada kisaran skor antara 46,15 sampai dengan 52,00; (2) Minat belajar siswa SMK AL Huda Turalak mempunyai rata-rata sebesar 47,32 maka termasuk kategori sedang karena berada pada kisaran skor antara 46,15 sampai dengan 52,00; (3) Terdapat pengaruh antara kualitas sarana dan prasarana terhadap minat belajar siswa di SMK Al-Huda Turalak. Hal ini
\end{abstract}


diperoleh dari analisis SPSS 20, dari analisis tersebut diketahui bahwa nilai sig (2-tailed) sebesar $0,001<0.05$, maka $\mathrm{H}_{0}$ ditolak dan nilai koefisien korelasinya sebesar 0.405 ini tergolong pada interpretasi sedang. Dari data di atas menunjukkan bahwa terdapat pengaruh antara kualitas sarana dan prasarana terhadap minat belajar siswa dalam pembelajaran PAI di SMK Al-Huda Turalak. Kemudian korelasinya sebesar $\mathrm{r}=0,405$ atau sebesar $40.5 \%$, dan angka tersebut terletak pada angka 0,410-0,60, berarti korelasi antara variabel X dan variabel $\mathrm{Y}$ itu sedang. Sedangkan 59.5\% minat siswa dipengaruhi oleh faktor lain.

\section{Keywords}

Islamic education, quality of facilities and infrastructure, interest in learning

\section{Pendahuluan}

Era globalisasi menuntut kesiapan yang lebih matang dalam segala hal. Bidang pendidikan merupakan salah satu andalan untuk mempersiapkan sumber daya manusia yang dibutuhkan untuk menghadapi tantangan zaman. Kegiatan belajar mengajar merupakan kegiatan yang paling pokok di lembaga pendidikan. Hal ini berarti, berhasil-tidaknya pencapaian tujuan pembelajaran tergantung pada proses belajar mengajar yang dialami siswa sebagai peserta didik di sekolah.

Setiap lembaga pendidikan, baik formal maupun non-formal, berusaha untuk memberikan dan melengkapi fasilitas yang ada di lembaganya untuk memenuhi kebutuhan semua warga sekolah, baik itu guru, staf-staf, peserta didik dan orang tua murid. Dalam upaya melengkapi fasilitas yang ada, sebuah lembaga pendidikan dikatakan maju apabila ketersediaan sarana dan prasarananya memadai berkaitan dengan proses belajar mengajar peserta didik. Proses belajar mengajar dapat meningkat dengan didukung adanya sarana dan prasarana yang memadai.

Sarana pendidikan merupakan sarana penunjang bagi belangsungnya proses belajar mengajar. Hal ini merupakan faktor yang harus diperhatikan oleh sebuah lembaga pendidikan karena mempengaruhi kelangsungan proses belajar mengajar di sekolah. Sarana dan prasarana sangat diperlukan untuk menunjang proses belajar mengajar, agar siswa lebih berminat dan mudah menerima penjelasan dari guru. Apabila sarana dan prasarana yang disediakan kurang, maka dapat mempengaruhi minat siswa untuk mengikuti proses belajar mengajar. Jika siswa memiliki minat dalam mengikuti proses belajar mengajar, maka faktor tersebut dapat meningkatkan prestasi belajar siswa.

Proses pendidikan memang memerlukan fasilitas atau peralatan. Hanya saja, semua fasilitas atau peralatan harus diadakan sesuai dengan kebutuhan. 
Jika semua peralatan dan fasilitas sudah ada harus dimanfaatkan dan dikelola secara baik dan benar. Kegiatan pengelolaan meliputi: perencanaan, pengadaan, pengawasan, penyimpanan, inventarisasi dan penghapusan, serta penataan. Sarana dan prasarana yang baik dapat menciptakan suasana yang menyenangkan, baik bagi guru maupun bagi murid.

Salah satu faktor yang mendukung keberhasilan program pendidikan dalam proses pembelajaran yaitu sarana dan prasarana. Prasarana pendidikan adalah salah satu sumber daya yang menjadi tolak ukur mutu sekolah. Aspek prasarana perlu peningkatan terus menerus seiring dengan perkembangan ilmu pengetahuan dan teknologi yang cukup canggih. Sarana dan prasarana adalah salah satu bagian input, sedangkan input merupakan salah satu subsistem. Sarana dan prasarana sangat perlu dilaksanakan untuk menunjang keterampilan siswa siap bersaing terhadap pesatnya teknologi. Sarana prasarana merupakan bagian penting yang perlu disiapkan secara cermat dan berkesinambungan sehingga dapat dijamin selalu terjadi KBM yang lancar dan efisien.

Minat adalah rasa lebih suka dan rasa ketertarikan pada suatu hal atau aktivitas, tanpa ada yang menyuruh (Slameto, 2010, p. 182). Minat belajar merupakan hal yang sangat penting yang harus ada pada diri peserta didik agar ia mampu belajar, karena dengan minat juga dapat menentukan prestasi belajar peserta didik itu sendiri. Dengan demikian, masalah pokok dalam penelitian ini, yaitu: (1) Bagaimana kualitas sarana dan prasarana di SMK Al-Huda Turalak Kecamatan Baregbeg Kabupaten Ciamis? (2) Bagaimana minat belajar siswa di SMK Al-Huda Turalak Kecamatan Baregbeg Kabupaten Ciamis? (3) Apakah terdapat pengaruh kualitas sarana prasarana terhadap minat belajar siswa di SMK Al-Huda Turalak Kecamatan Baregbeg Kabupaten Ciamis?

\section{Kajian Teoritik}

\section{Pengertian Sarana dan Prasarana}

Menurut Sutisna (1985, p. 21), secara bahasa, prasarana diartikan sebagai alat tidak langsung untuk mencapai tujuan dalam pendidikan. Misalnya lokasi atau tempat, bangunan sekolah dan lapangan olahraga. Sedangkan sarana berarti alat langsung untuk mencapai tujuan pendidikan. Misalnya ruang, buku, perpustakaan, laboratorium dan lain-lain.

Sarana dan prasarana merupakan suatu kondisi yang dipersyaratkan untuk berlangsungnya kegiatan belajar mengajar di sekolah (Suryadi, 2009, p. 124). Berdasarkan hal tersebut, maka sekolah harus memiliki standar fasilitas pembelajaran, agar proses pembelajaran berjalan dengan lancar.

Mulyasa (2007, p. 49) menjelaskan bahwa sarana pendidikan adalah peralatan dan perlengkapan yang secara langsung dipergunakan dan untuk 
menunjang proses pendidikan, khususnya dalam proses belajar-mengajar, seperti gedung, ruang kelas, meja, kursi serta alat-alat dan media pengajaran. Adapun yang dimaksud prasarana pendidikan atau pengajaran dalam proses pembelajaran, seperti halaman sekolah, kebun sekolah, dan jalan menuju sekolah. Selain itu, Bafadal (2004, p. 2) menyatakan bahwa sarana pendidikan adalah semua perangkat peralatan, bahan dan perabot yang secara langsung digunakan dalam proses pendidikan di sekolah. Sedangkan prasarana pendidikan adalah semua perangkat kelengkapan dasar yang secara tidak langsung menunjang pelaksanaan proses pendidikan di sekolah.

Sarana merupakan perlengkapan yang diperlukan untuk menyelenggarakan pembelajaran yang dapat dipindah-pindah. Adapun prasarana ialah fasilitas dasar yang diperlukan untuk menjalankan fungsi satuan pendidikan (Permendiknas No. 24/2007). Dalam Peraturan Pemerintah No 19 Tahun 2005 tentang Standar Nasional Pendidikan, Bab VII Pasal 42 disebutkan bahwa: (1) Setiap satuan pendidikan wajib memiliki sarana yang meliputi perabot, peralatan pendidikan, media pendidikan, buku dan sumber belajar lainnya, bahan habis pakai, serta perlengkapan lain yang diperlukan untuk menunjang proses pembelajaran yang teratur dan berkelanjutan; (2) Setiap satuan pendidikan wajib memiliki prasarana yang meliputi lahan, ruang kelas, ruang pimpinan satuan pendidikan, ruang pendidik, ruang tata usaha, ruang perpustakaan, ruang laboratorium, ruang bengkel kerja, ruang unit produksi, ruang kantin, instalasi daya dan jasa, tempat berolah raga, tempat beribadah, tempat bermain, tempat berkreasi, dan ruang/tempat lain yang diperlukan untuk menunjang proses pembelajaran yang teratur dan berkelanjutan.

Berdasarkan pengertian sarana dan prasarana di atas, dapat ditarik kesimpulan bahwa sarana dan prasarana merupakan komponen dalam proses pembelajaran yang mendukung potensi masing-masing peserta didik di setiap satuan pendidikan, baik formal maupun non-formal. Pengertian sarana pendidikan itu sendiri adalah segala peralatan atau barang baik bergerak ataupun tidak yang digunakan secara langsung untuk proses pendidikan, sedangkan sarana prasarana adalah semua perangkat yang tidak secara langsung digunakan untuk proses pendidikan. Sarana dan prasarana merupakan suatu kebutuhan yang harus tersedia untuk mendukung kegiatan pembelajaran dan peningkatan mutu pendidikan serta dalam rangka mewujudkan tujuan pendidikan nasional.

Sarana dan prasarana yang dibutuhkan di sekolah tidak selalu sama. Hal tersebut tergantung pada tingkatan sekolah. Misalnya sekolah dasar, sekolah menengah dan sekolah lanjutan atas. Selain itu, visi-misi dan kebijakan sekolah juga mempengaruhi improvisasi sarana dan prasarana suatu sekolah. 
Adapun macam-macam sarana dan prasarana yang diperlukan demi kelancaran dan keberhasilan kegiatan proses pendidikan adalah: (1) Ruang kelas tempat siswa dan guru melaksanakan proses kegiatan belajar mengajar; (2) Ruang perpustakaan tempat koleksi berbagai jenis bacaan bagi siswa dan dari sinilah siswa dapat menambah pengetahuan; (3) Ruang laboratorium tempat siswa mengambangkan pengetahuan sikap dan keterampilan serta tempat meneliti dengan menggunakan media yang ada untuk memecahkan suatu masalah atau konsep pengetahuan; (4) Ruang kesenian adalah tempat berlangsungnya kegiatan-kegiatan seni; 5) Fasilitas olahraga tempat berlangsungnya latihan-latihan olahraga (Nawawi, 2001, p. 69).

Terkait Sarana dan prasarana, ketersediaan lahan dan ruang merupaka unsur utama dalam pelalksanaan aktifitas belajar-mengajar. Secara administrative, lahan yang diperlukan untuk mendirikan sekolah atau perguruan tinggi harus disertai dengan tanda bukti yang sah dan lengkap (sertifikat). Adapun jenis lahan tersebut harus memenuhi beberapa kriteria antara lain: (a) Lahan terbangun adalah lahan yang diatasnya berisi bangunan; (b) Lahan terbuka adalah lahan yang belum ada bangunan diatasnya; (c) lahan kegiatan praktek adalah lahan yang digunakan untuk pelaksanaan kegiatan praktek; (d) lahan pengembagan adalah lahan yang dibutuhkan untuk pengembangan bangunan dan kegiatan praktek (Nawawi, 2001, p. 79). Sedangkan lokasi lahan tersebut harus berada di wilayah pemukiman yang sesuai dengan cakupan wilayah, sehingga mundah dijangkau dan aman dari gangguan bencana alam dan lingkungan yang kurang baik.

Adapun ruang, ditinjau dari fungsinya, ruang dapat dikelompokan ke dalam: (a) Ruang pendidikan; (b) Ruang administrasi; (c) Ruang penunjang (d) Ruang alat dan media pendidikan; (e) Ruang buku atau bahan ajar; (f) Sarana dan prasaran pendidikan

\section{Minat Belajar}

Dalam hal belajar, minat sangat besar pengaruhnya terhadap proses dan hasil belajar. Jika seseorang tidak berminat untuk mempelajari sesuatu hal, maka tidak diharapkan akan berhasil dengan baik.

Menurut Muhibbin Syah (1999, p. 152), minat (interest) berarti kecenderungan dan kegairahan yang tinggi atau keinginan yang besar terhadap sesuatu. Minat adalah rasa lebih suka dan rasa ketertarikan pada suatu hal atau aktivitas, tanpa ada yang menyuruhnya. Minat pada dasarnya adalah penerimaan akan suatu hubungan antara diri sendiri dengan sesuatu di luar diri. Semakin kuat atau semakin dekat hubungan tersebut, semakin besar minatnya (Djaali, 2009, p. 121). Minat adalah perasaan yang menyatakan bahwa suatu aktivitas pekerjaan atau objek itu berharga atau berarti bagi 
individu (Chaplin, 2006, p. 256). Menurut Slameto (2010, p. 180), minat adalah suatu rasa lebih suka dan rasa ketertarikan pada suatu hal atau aktivitas, tanpa ada yang menyuruh. Minat diimplementasikan melalui partisipasi aktif dalam sesuatu maka siswa tersebut cenderung untuk memperhatikan terhadap sesuatu yang diminatinya dan mengikuti kegiatan yang dilakukan dengan rasa senang.

Berdasarkan pendapat di atas, minat merupakan suatu ketertarikan seseorang untuk memperhatikan atau terlibat dalam aktivitas belajar secara aktif. Guru menciptakan suasana belajar yang memungkinkan siswa aktif (bertanya, mempertanyakan dan mengemukakan pendapat). Minat merupakan kecenderungan jiwa seseorang kepada seseorang (biasanya disertai dengan perasaan senang), karena itu merasa ada kepentingan dengan sesuatu itu. Menurut Bernard, minat timbul tidak secara tiba-tiba/spontan, melainkan timbul tidak akibat dari partisipasi, pengalaman, kebiasaan pada waktu belajar atau bekerja (Sardiman, 1986, p. 76).

Menurut Crow \& Crow (1986, pp. 302-303), sebagaimana dikutip Abror (1993, p. 112), minat atau interest bisa berhubungan daya gerak yang mendorong kita cenderung merasa tertarik kepada orang, benda, atau kegiatan ataupun pengalaman yang efektif yang dirangsang oleh kegitan itu sendiri. Minat berhubungan dengan gaya gerak yang mendorong seseorang untuk menghadapi atau berurusan dengan orang, benda, kegiatan, pengalaman yang dirangsang oleh kegiatan itu sendiri

Minat dapat diekspresikan melalui pernyataan yang menunjukkan bahwa siswa lebih menyukai suatu hal daripada hal lainnya, dapat pula dimanifestasikan melalui partisipasi dalam suatu aktivitas. Minat tidak dibawa sejak lahir, melainkan diperoleh kemudian. Dengan demikian minat belajar dapat kita definisikan sebagai ketertarikan dan kecenderungan yang tetap untuk memperhatikan dan terlibat dalam aktivitas belajar karena menyadari pentingnya atau bernilainya hal yang dipelajari.

Menurut Totok Susanto (1998), beberapa faktor yang mempengaruhi minat belajar siswa, adalah sebagai berikut: (1) Motivasi dan cita-cita; (2) Keluarga; (3) Peranan guru; (4) Sarana dan prasarana; (5) Teman pergaulan; (6) Media masa.

Faktor-faktor yang mempengaruhi minat juga dipengaruhi faktor-faktor yang bersifat internal maupun eksernal. Faktor internal adalah sesuatu yang membuat peserta didik berminat yang datangnya dari dalam diri. Menurut Reber, sebagaimana dikutip Muhibbin Syah (Syah, 1999, p. 137), faktor internal tersebut meliputi, pertama, perhatian. Perhatian merupakan konsentrasi atau aktivitas jiwa seseorang terhadap pengamatan, pengertian ataupun yang lainnya dengan mengesampingakan hal lain dari pada itu. Kedua, 
ketertarikan. Peserta didik yang berminta terhadap suatu pelajaran makaia akan mengalami perasaan ketertarikan untuk belajar. Ketiga, motivasi. Motivasi merupakan suatu usaha atau pendorong yang dilakukan secar sadar untuk melakukan tindakan belajar dan mewujudkan tindakan perilaku yang terarah demi pencapaian tujuan yang diharapkan dalam situasi interaksi belajar yang akan mendorong peserta didik semangat untuk belajar. Keempat, pengetahuan. Peserta didik yang berminat terhadap pelajaran maka ia akan mempunyai pengetahuan yang luas tentang pelajaran serta bagaimana manfaat belajar dalam kehidupan sehari-hari.

Sedangkan faktor eksternal adalah sesuatu yang membuat peserta didik berminat yang datangnya dari luar diri seperti: keluarga, guru, dan lingkungan. Faktor-faktor eksternal tersebut adalah minat yang terdiri dari: (1) Aspek kognitif. didasari pada konsep perkembangan di masa anak-anak mengenai halhal yang menghubungkannya dengan minat. Minat pada aspek kognitif berpusat seputar pertanyaan-pertanyaan sehingga seseorang yang memiliki minat terhadap suatu aktivitas akan dapat mengerti dan mendapatkan banyak manfaat dari suatu aktivitas yang dilakukannya; (2) Aspek afektif. Aspek afektif atau emosi yang mendalam merupakan konsep yang menampakkan aspek kognitif dari minat yang ditampilkan dalam sikap terhadap aktivitas yang diminatinya; (3) Aspek psikomotorik. Aspek psikomotor lebih mengorientasikan kepada proses tingkah laku atau pelaksana sebagai tindak lanjut dari nilai yang didapat melalui aspek kognitif dan diinternalisasikan melalui aspek afektif sehingga mengorganisasi dan diaplikasikan dalam bentuk nyata melalui aspek psikomotor. Seseorang yang memiliki minat tinggi terhadap suatu hal akan berusaha mewujudkannya sebagai pengungkapan ekspresi atau tindakan nyata dari keinginannya.

Minat mempunyai peranan yang sangat penting dalam kegiatan belajar mengajar. Ada beberapa pendapat tentang fungsi minat, antara lain penunjang keberhasilan belajar. Dalam pengertian, salah satu syarat agar peserta didik dapat berhasil belajar adalah minat yang tinggi (Sagala, 2007, p. 57). Apabila siswa mempunyai minat yang tinggi terhadap suatu materi pembelajaran, maka siswa akan mepelajari materi tersebut dengan perasaan senang dan akan memunculkan rasa ingin tahu yang lebih besar lagi.

Minat juga sangat berpengaruh terhadap kepuasan dalam belajar. Minat selalu diikuti dengan perasaan senang dan dari situ diperoleh kepuasan (Slameto, 2010, p. 57). Apabila mengerjakan atau mempelajari sesuatu diikuti dengan rasa senang, maka akan menghasilkan kepuasan tersendiri setelah mengerjakan atau mempelajari materi tersebut dan biasanya rasa senang akan mendorong orang untuk melakukan atau untuk mempelajari sampai dia merasa berhasil dan menghasilkan kepuasan. 
Minat belajar yang ada pada diri seorang peserta didik ditunjukkan dengan beberapa indikator, yaitu: tertarik pada manfaat belajar, usaha memahami materi pembelajaran, membaca buku pelajaran, bertanya kepada guru di dalam kelas, bertanya pada teman, bertanya pada orang lain, serta mengerjakan soal yang diberikan oleh guru.

Berdasarkan uraian di atas, dapat disimpulkan bahwa minat belajar adalah ketertarikan pada pembelajaran, yang diperoleh melalui usaha, dapat dimanifestasikan melalui suatu aktivitas, dan ditunjukkan dengan beberapa indikator, yaitu tertarik pada manfaat belajar, usaha memahami materi pembelajaran, membaca buku pelajaran, bertanya kepada guru di dalam kelas, bertanya pada teman, bertanya pada orang lain, serta mengerjakan soal yang diberikan oleh guru.

Menurut Djamarah (2002, p. 132), indikator minat belajar yaitu rasa suka/senang, pernyataan lebih menyukai, adanya rasa ketertarikan kesadaran untuk belajar tanpa disuruh, berpartisipasi dalam aktivitas belajar, serta memberikan perhatian. Dari pendapat ahli tersebut diatas, maka yang dimaksud rasa suka/senang, rasa ketertarikan di sana adalah adanya kesadaran atau sikap/respon siswa yang rajin dan tekun dalam belajar, rajin dalam mengerjakan tugas, serta disiplin dalam belajar.

Sedangkan menurut Slameto (2010, p. 180), beberapa indikator minat belajar yaitu: perasaan senang, ketertarikan, penerimaan dan keterlibatan siswa. Dari pendapat ahli tersebut di atas, maka yang dimaksud perasaan senang adalah perasaan siswa yang tidak merasa terbebani pada saat belajar, ikut aktip saat proses belajar berlangsung dan selalu memperhatikan guru pada saat menjelaskan.

Berdasarkan dua pendapat diatas, dapat disimpulkan bahwa indikator minat belajar seseorang dapat dilihat dari bagaimana sikap/respon siswa pada saat belajar. Beberapa aspek yaitu rajin dalam belajar, tekun dalam belajar, rajin dalam mengerjakan tugas, disiplin dalam belajar dan memiliki jadwal belajar sendiri. Adapun kaitan dengan sarana prasarana yaitu salah satu aspek yang diperlukan dalam meningkatkan minat belajar siswa.

Berdasarkan uraian di atas, maka hipotesis yang dapat dikemukakan peneliti pada penelitian ini yaitu terdapat pengaruh yang signifikan antara kualitas sarana dan prasarana terhadap minat belajar siswa dalam pembelajaran PAI di SMK Al-Huda Turalak Kec. Baregbeg Kab. Ciamis. Hipotesis adalah suatu dugaan sementara yang kebenarannya perlu dibuktikan dalam suatu penelitian. Hipotesis merupakan jawaban sementara terhadap rumusan masalah penelitian, dimana rumusan masalah penelitian telah dinyatakan didalam bentuk kalimat pertanyaan. Dikatakan sementara, karena jawaban yang diberikan baru didasarkan pada teori yang relevan, belum didasarkan pada 
fakta-fakta empiris yang diperoleh melalui pengumpulan data. Hipotesis ini dibagi menjadi dua macam, yakni ada hipotesis penelitian dan hipotesis statistik. Hipotesis penelitian adalah jawaban sementara terhadap rumusan masalah penelitian, sedangkan hipotesis statistik itu ada bila peneliti bekerja dengan sampel (Sugiyono, 2011, p. 70).

\section{Metode Penelitian}

Jenis penelitian di sini adalah jenis penelitian kuantitatif lapangan, yaitu salah satu metode pengumpulan data dalam penelitian kuantitatif yang tidak memerlukan pengetahuan mendalam akan literatur yang digunakan dan kemampuan tertentu dari pihak peneliti. Dengan karakteristik masalah yang diteliti dan pendekatan penelitian yang diguna kan (kuantitatif), maka yang diutamakan adalah respon yang kuantifikasi agar dapat diolah secara statistik, sedangkan yang menyimpang dari itu tidak dihiraukan (Saebani, 2008, p. 185).

Pendekatan kuantitatif menggunakan cara kerja perhitungan statistik (Hariwijaya, 2007, p. 71). Data dalam penelitian ini akan diolah dan hasilnya berupa angka dan analisis deskriptif dalam bentuk prosentase, sedangkan alat untuk mengolahnya menggunakan SPSS. Jenis data yang digunakan dalam penelitian ini adalah data primer. Data primer adalah sumber data yang langsung memberikan data kepada pengumpul data (Sugiyono, 2011, p. 156). Data yang digunakan adalah data cross section, karena data dikumpulkan dari periode waktu observasi dan dalam suatu periode waktu tertentu yang relatif lebih pendek.

Adapun metode yang digunakan dalam skripsi ini adalah penelitian korelasi. Korelasi berguna untuk menentukan hubungan antar dua variabel penelitian. Koefisien korelasi yang terbentuk dari hubungan dua variabel memiliki dua makna, yaitu arah hubungan (positif dan negatif) dan besar hubungan (lemah, moderat, dan kuat) (Trihendardi, 2013, p. 134). Tujuan dilakukannya analisis korelasi antara lain: (1) Mencari bukti terdapat tidaknya hubungan (korelasi) antar variabel (2) Melihat besar-kecilnya hubungan antar variabel; (3) Memperoleh kejelasan dan kepastian apakah hubungan tersebut berarti (meyakinkan/signifikan) atau tidak berarti (tidak meyakinkan) .

\section{Hasil dan Pembahasan}

Data dalam penelitian ini terdiri atas dua variabel, yaitu kualitas sarana dan prasarana sebagai variabel 1 (variabel $\mathrm{X}$ ) dan minat belajar siswa pada mata pelajaran Pendidikan Agama Islam sebagai variabel 2 (variavel Y). 


\section{Kualitas Sarana dan Prasarana (Variabel X)}

Untuk mengetahui data tentang kualitas sarana dan prasarana peneliti memberikan kuesioner kepada 65 orang responden. Setiap kuesioner berisi 13 pernyataan yang harus ditanggapi oleh masing-masing responden (siswa kelas X, XI dan XII TKJ).

Untuk menanggapi seluruh pertanyaan dalam angket tersebut, penulis menyediakan lima pilihan tanggapan dengan kriteria skornya masing-masing yaitu: (a) Sangat setuju dengan skor 5; (b) Setuju dengan skor 4; (c) Ragu-ragu dengan skor 3; (d) Tidak setuju dengan skor 2; (e) Sangat tidak setuju dengan skor 1.

Dari pengumpulan data tersebut, penulis mendapatkan skor kualitas sarana dan prasarana sebagai berikut:

Berdasarkan hasil perhitungan, dapat diketahui bahwa:

a. Tendensi sentral, yakni:

1) Mean sebesar 46,83 . Harga mean tersebut penulis konversikan dengan menggunakan pedoman konversi. Dengan demikian, nilai mean sebesar 46,83 tergolong pada klarifikasi sedang karena berada pada kisaran skor antara 46,15 sampai dengan 52,00

2) Mediannya adalah 47,00

3) Modusnya adalah 47,00

b. Variabilitas, yakni:

1) Standar deviasinya adalah 4, 68231

2) Variannya adalah 21,924

3) Quartilnya (Q) adalah: $\mathrm{Q}_{1}=45,00 ; \mathrm{Q} 2=47,00$ : $\mathrm{Q} 3=49,50$

4) Desil (D) nya adalah: $D_{1}=40,00 ; D_{2}=44,00 ; D_{3}=45,00 ; D_{4}=46,00$; $\mathrm{D}_{5}=47,00 ; \mathrm{D}_{6}=48,00 ; \mathrm{D}_{7}=49,00 ; \mathrm{D}_{8}=50,00 ; \mathrm{D}_{9}=52,00$

5) Persentilnya $(\mathrm{P})$ adalah: $\mathrm{P}_{10}=40,00 ; \mathrm{P}_{20}=44,00 ; \mathrm{P}_{25}=45,00 ; \mathrm{P}_{30}=$ 45,$00 ; \mathrm{P}_{40}=46,00 ; \mathrm{P}_{50}=47,00 ; \mathrm{P}_{60}=48,00 ; \mathrm{P}_{70}=49,00 ; \mathrm{P}_{75}=49,50$; $\mathrm{P}_{80}=50,00 ; \mathrm{P}_{90}=52,00$

\section{Minat Belajar Siswa (Variabel Y)}

Untuk mengetahui data tentang Minat belajar siswa peneliti memberikan kuesioner kepada 65 orang responden. Setiap kuesioner berisi 13 pernyataan yang harus ditanggapi oleh masing-masing responden (siswa kelas X, XI dan XII TKJ).

Untuk menanggapi seluruh pertanyaan dalam angket tersebut, penulis menyediakan Untuk menanggapi seluruh pertanyaan dalam angket tersebut, penulis menyediakan lima pilihan tanggapan dengan kriteria skornya masingmasing yaitu: (a) Sangat setuju dengan skor 5; (b) Setuju dengan skor 4; (c) 
Ragu-ragu dengan skor 3; (d) Tidak setuju dengan skor 2; (e) Sangat tidak setuju dengan skor 1 .

Dari pengumpulan data tersebut, penulis mendapatkan skor minat belajar siswa sebagai berikut:

Berdasarkan hasil perhitungan, dapat diketahui bahwa:

a. Tendensi Sentral, yakni:

1) Mean sebesar 47,32 . Harga mean tersebut penulis konversikan dengan menggunakan pedoman konversi. Dengan demikian, nilai mean sebesar 47,32 tergolong pada klarifikasi sedang karena berada pada kisaran skor antara 46,15 sampai dengan 52 .

2) Mediannya adalah 48,00

3) Modusnya adalah 50,00

b. Variabilitas, yakni:

1) Standar deviasinya adalah 4, 06243

2) Variannya adalah 16,503

3) Quartilnya $(\mathrm{Q})$ adalah: $\mathrm{Q}_{1}=45,00 ; \mathrm{Q} 2=48,00$ : $\mathrm{Q} 3=50,00$

4) Desil (D) nya adalah: $D_{1}=41,60 ; D_{2}=44,20 ; D_{3}=45,00 ; D_{4}=47,00$; $\mathrm{D}_{5}=48,00 ; \mathrm{D}_{6}=49,00 ; \mathrm{D}_{7}=50,00 ; \mathrm{D}_{8}=50,80 ; \mathrm{D}_{9}=52,00$

5) Persentilnya $(\mathrm{P})$ adalah: $\mathrm{P}_{10}=41,60 ; \mathrm{P}_{20}=44,20 ; \mathrm{P}_{25}=45,00 ; \mathrm{P}_{30}=$ 45,$00 ; \mathrm{P}_{40}=47,00 ; \mathrm{P}_{50}=48,00 ; \mathrm{P}_{60}=49,00 ; \mathrm{P}_{70}=50,00 ; \mathrm{P}_{75}=50,00$; $\mathrm{P}_{80}=50,80 ; \mathrm{P}_{90}=52,00$

Menurut Priyatno (2008, p. 28), uji normalitas dilakukan dengan tujuan untuk mengetahui normal atau tidaknya distribusi suatu data. Uji normalitas ini penulis lakukan pada kedua variabel, yakni kualitas sarana dan prasarana (variable X) dan minat belajar siswa (variabel Y).

Dalam melakukan uji normalitas suatu data variabel $\mathrm{X}$ penulis menggunakan uji One Sample Kolmogorov-Smirnov dengan taraf signifikansi 0,05 . Uji normalitas ini penulis lakukan dengan menggunakan program SPSS versi 20, sehingga didapat hasil bahwa dari hasil uji normalitas di atas tampak pada kolom Kolmogorov-Smirnov dengan taraf signifikansi 0,05. Bahwa nilai Sig $0,006<0,05$. Maka dapat disimpulkan bahwa data variabel $\mathrm{X}$ berdistribusi tidak normal.

Adapun untuk variabel $\mathrm{Y}$ hasil uji normalitasnya adalah bahwa uji normalitas di atas tampak pada kolom Kolmogorov-Smirnov dengan taraf signifikansi 0,05 . Bahwa nilai Sig 0,001 $<0,005$. Maka dapat disimpulkan bahwa data variabel Y berdistribusi tidak normal.

Dari hasil di atas, dapat disimpulkan bahwa data pada variabel $\mathrm{X}$ dan variabel $\mathrm{Y}$ berdistribusi tidak normal. 
Adapun uji linearitas, menurut Priyatno (2008, p. 36), bertujuan untuk mengetahui apakah suatu variabel $\mathrm{X}$ dan $\mathrm{Y}$ memiliki hubugan yang linier atau tidak secara signifikansi. Uji linieritas ini dilakukan dengan program SPSS versi 20 pada taraf signifikansi 0,05 . Variabel $\mathrm{X}$ dan $\mathrm{Y}$ dikatakan mempunyai hubungan yang linieritas bila signifikansi kurang dari 0,05. Berikut adalah hasil ujian linieritas terhadap kedua variabel.

Dari hasil data di atas, dapat diketahui bahwa nilai signifikansi pada linierity adalah sebesar 0,005. Karena signifikansi 0,005 $<0,05$, maka dapat disimpulkan bahwa antara variabel $\mathrm{X}$ dan variabel $\mathrm{Y}$ terdapat hubungan linier yang signifikan.

Uji regresi dilakukan penulis dengan metode analisis regresi linier sederhana, yaitu, sebagaimana dipaparkan Priyatno (2008, p. 66), dilakukan dengan tujuan untuk mengetahui arah hubungan antara kedua variabel. Kedua variable tersebut berkaitan dengan kualitas sarana dan prasarana (variabel $\mathrm{X}$ ) dengan minat belajar siswa (variabel Y). Berikut adalah data untuk kedua variabel setelah diolah penulis menggunakan program SPSS versi 20 sehingga diperoleh hasil sebagai berikut:

$$
\begin{aligned}
& Y^{1}=a+b X \\
& Y^{1}=33,354+0,298 X
\end{aligned}
$$

Angka di atas angka ini dapat diartikan bahwa pertama, Konstanta sebesar 33,354, maksudnya apabila variabel X (kualitas sarana dan prasarana) nilainya adalah nol, maka variabel Y (minat belajar siswa) nilainya positif, yaitu sebesar 33,354. Kedua, koefisien regresi variabel X (kualitas sarana dan prasarana) sebesar 0,298 , artinya jika variabel X (kualitas sarana dan prasarana) nilainya 1 , maka variabel Y (minat belajar siswa ) akan mengalami peningkatan sebesar 0 , 298. Koefisien bernilai positif, artinya terjadi pengaruh positif antara variabel $\mathrm{X}$ terhadap variabel Y. Dengan kata lain, semakin berkualitas sarana dan prasarana, maka minat belajar siswa akan semakin meningkat.

Dalam menentukan nilai koefisien korelasi, penulis menggunakan metode korelasi Spearman's rho, alasan penggunaan metode ini adalah karena kedua variabel tidak berasumsi distribusi normal. Maka, berdasarkan tabel di atas bahwa $\mathrm{N}$ atau jumlah data penelitian adalah 65, kemudian penulis memperoleh koefisien korelasi antara variabel $\mathrm{X}$ dengan variabel $\mathrm{Y}$ sebesar $0,001<0.05$. Dari data di atas menunjukan bahwa terdapat pengaruh antara kualitas sarana dan prasarana terhadap minat belajar siswa dalam pembelajaran PAI di SMK Al-Huda Turalak. Kemudian korelasinya sebesar $r=0,405$ atau sebesar $40.5 \%$, dan angka tersebut terletak pada angka 0,410-0,60, berarti korelasi antara variabel X dan variabel Y itu sedang. Sedangkan $59.5 \%$ minat siswa dipengaruhi oleh faktor lain. 


\section{Kesimpulan}

Setelah penulis meneliti pengaruh kualitas sarana dan prasarana terhadap minat belajar siswa di SMK Al-Huda Turalak Kecamatan Baregbeg Kabupaten Ciamis, maka penulis dapat mengambil kesimpulan, pertama, kualitas sarana dan prasarana di SMK Al-Huda Turalak mempunyai nilai rata-rata sebesar 46,83 tergolong pada klasifikasi sedang, karena berada pada kisaran skor antara 46,15 sampai dengan 52,00. Kedua, sedangkan minat belajar siswa SMK AlHuda Turalak mempunyai rata-rata sebesar 47,32 tergolong pada klasifikasi sedang, karena berada pada kisaran skor antara 46,15 sampai dengan 52,00. Ketiga, terdapat pengaruh antara kualitas sarana dan prasarana terhadap minat belajar siswa di SMK Al-Huda Turalak. Hal ini diperoleh dari analisis SPSS 20, dari analisis tersebut diketahui bahwa nilai sig (2-tailed) sebesar 0,001<0.05, maka $\mathrm{H}_{0}$ ditolak dan nilai koefisien korelasinya sebesar 0.405 ini tergolong pada interpretasi sedang.

Dari data di atas menunjukan bahwa terdapat pengaruh antara kualitas sarana dan prasarana terhadap minat belajar siswa dalam pembelajaran PAI di SMK Al-Huda Turalak. Kemudian korelasinya sebesar $r=0,405$ atau sebesar $40.5 \%$, dan angka tersebut terletak pada angka 0,410-0,60, berarti korelasi antara variabel $\mathrm{X}$ dan variabel $\mathrm{Y}$ itu sedang. Sedangkan $59.5 \%$ minat siswa dipengaruhi oleh faktor lain.

\section{DAFTAR PUSTAKA}

Abror. (1993). Psikologi Pendidikan. Yogyakarta: Tiara Wacana.

Bafadal, I. (2004). Manajemen Perlengkapan Sekolah: Teori dan Aplikasinya. Jakarta: Bumi Aksara.

Chaplin, J. P. (2006). Kamus Lengkap Psikologi. (Kartono, Trans.) Jakarta: PT Raja Grafindo Persada.

Crow, L. D., \& Crow, A. (1986). Psikologi Pendidikan. Yogyakarta: Nur Cahaya.

Djaali. (2009). Psikologi Pendidikan. Jakarta: Bumi AKsara.

Djamarah, S. B., \& Zain, A. (2002). Strategi Belajar Mengajar. Jakarta: PT Rineka Cipta.

Hariwijaya, M. (2007). Metodologi dan Teknik Penulisan Skripsi, Tesis dan Disertasi. Yogyakarta: Elmatera Publishing.

Mulyasa, E. (2007). Menjadi Guru Profesional: Menciptakan Pembelajaran Kreatif dan Menyenangkan. Bandung: Rosdakarya. 
Nawawi, H. (2001). Administrasi Pendidikan: Suatu Pengantar. Jakarta: PT Gunung Agung.

Priyatno, D. (2008). Mandiri Belajar SPSS bagi Mahasiswa dan Umum. Yogyakarta: MediaKom.

Saebani, B. A. (2008). Metode Penelitian. Bandung: Pustaka Setia.

Sagala, S. (2007). Konsep dan Makna Pembelajaran. Bandung: Alfabeta.

Sardiman, A. M. (1986). Interaksi dan Motivasi Belajar-Mengajar. Jakarta: CV Rajawali .

Slameto. (2010). Belajar dan Faktor-Faktor yang Mempengarubinya. Jakarta: Rineka CIpta.

Sugiyono. (2011). Statistika untuk Penelitian. Bandung: Alfabeta.

Suryadi. (2009). Manajemen Mutu Berbasis Sekolah. Bandung: PT Sarana Pancakarya Nusa.

Susanto, T. (1998). Faktor-Faktor yang Mempengarubi Minat Belajar. Semarang: IKIP Semarang.

Sutisna, O. (1985). Administrasi Pendidikan: Dasar Teoritis untuk Praktek Profesional. Bandung: Angkasa.

Syah, M. (1999). Psikologi Belajar. Ciputat: PT Logos Wacana Ilmu.

Trihendardi, C. (2013). Step by Step SPSS 20 Analisis Data Statistik. Yogyakarta: ANDI. 